\title{
YouTube Podcasting, the New Orality, and Diversity of Thought: Intermediality, Media History, and Communication Theory as Methodological Approaches
}

Christer Johansson

New media in the postdigital age are sometimes said to promote political polarization, antagonism, and different kinds of hate speech. This is especially true of social media, like Facebook and Twitter. We are by now all familiar with internet trolls stirring the pot, trying to start shitstorms, and downright online harassment. However, the short and crude interactions on Twitter and in comment sections on different platforms are challenged by a different trend, what we might brand "long-form conversation podcasting," a form of talk show with a host and invited guests. ${ }^{\text {I }}$ In this chapter I explore two exponents of this trend, the YouTube show The Joe Rogan Experience and its Swedish cousin, Hur kan $v i$ ? (How Can We?). ${ }^{2}$ The Joe Rogan Experience was launched on December 24, 2009, and has by now published more than I,400

I This label is inspired by the website of The Joe Rogan Experience, https:// www.joerogan.com. For more on podcasting, see: Dario Llinares, Neil Fox, and Richard Berry, eds., Podcasting New Aural Cultures and Digital Media (Cham: Springer International Publishing, 2018).

${ }^{2}$ Hur kan vi? is directly inspired by The Joe Rogan Experience, as is evident in this clip: Hur kan vi?, "Därför ska jag tatuera in Joe Rogans ansikte på min rumpa" ("That is why I will tattoo Joe Rogan's face on my butt"), YouTube, December 9, 20I9, https:/www.youtube.com/watch?v=LLY 3 cItp2so.

How to cite this book chapter:

Johansson, Christer. "YouTube Podcasting, the New Orality, and Diversity of Thought: Intermediality, Media History, and Communication Theory as Methodological Approaches." In Digital Human Sciences: New ObjectsNew Approaches, edited by Sonya Petersson, 253-284. Stockholm: Stockholm University Press, 202I. DOI: https://doi.org/Io.I6993/bbk.k. License: CC-BY. 
episodes. It is published on YouTube three to four times a week (until recently it aired live). Hur kan vi? was launched on May 2I, 20I 8 , and has published 88 episodes. It is recorded live-ontape, in real time; the episodes are published once a week, and a couple of times every season the show organizes public live events streaming on YouTube. Both shows have sparked off debate on free speech, and some of the invited guests have been questioned and denounced as controversial and/or undemocratic.

The research question I would like to confront The Joe Rogan Experience and Hur kan vi? with is a very simple one: what are they? It relates to the digital human sciences' concern with "the study of digital objects and environments and their significance for human beings and society," and more specifically to the "interaction between human beings in digital systems and between human beings and digital entities" part of the definition of the field. ${ }^{3}$ I will try to show how this YouTube phenomenon, the long-form conversation podcast, can be analyzed from a digital human sciences perspective, combining three transdisciplinary approaches: (I) an intermedial analysis focusing on the relations between media and modalities, (2) a media-historical analysis of the remediational structures and cultural status of orality, and (3) a communication-theoretical analysis of the current channeling of information. In other words, I will successively describe the podcasts as intermedial objects, their position in media history, and their place in today's medial infrastructure.

\section{Intermediality and Multimodality: A Formal Analysis}

The first step in the analysis of the podcasts is to characterize what distinguishes these digital entities as intermedial constellations. I will describe them in terms of media relations and as multimodal artifacts. A number of researchers, influenced by semiotics, such as Werner Wolf, Irina O. Rajewsky, and Hans Lund, working in the field of intermediality studies, are concerned with schematizing media interrelations in typologies based on formal qualities. We can distinguish between "extracompositional" and "intracompositional" intermediality (intermediality in the narrow sense), to

\footnotetext{
3 See the introduction to this volume.
} 
begin with. Extracompositional intermediality means, for example, transmedial qualities common to all or many representations, such as narrativity or rhythm, or transformations, such as film adaptations of novels. ${ }^{4}$ As I try to show later in this chapter, the podcasts could be viewed as transformations of sorts, mediations of spoken dialogue, and remediations of radio as a medium, but for now I concentrate on various aspects of their intracompositional intermediality. Furthermore, within this category, we can distinguish between "intermedial reference" ("using a single semiotic system") and "plurimediality" ("displaying signifiers that appear to belong to more than one semiotic system")..$^{5}$ Intermedial references, that is, references to an absent medium by way of the first medium's own media specific means, may be implicit (intermedial imitation, such as literature imitating film or music) or explicit (intermedial thematization, such as literature about film or music). Within the category of plurimediality, two, or more, distinct media are present in one object in their own materiality. Here, we can distinguish between intermedial interreference (such as illustrations or picture and title), combination (such as comics, opera, or video art), and fusion (concrete poetry or verbal signs in a pictorial representations).

The Joe Rogan Experience and Hur kan vi? are inherently intermedial, that is, a combination of sound, mostly linguistic sounds,

4 These categories and distinctions are Werner Wolf's, "The Relevance of Mediality and Intermediality to Academic Studies of English Literature [2008]," in Selected Essays on Intermediality by Werner Wolf (I992-20I4): Theory and Typology, Literature-Music Relations, Transmedial Narratology, Miscellaneous Transmedial Phenomena, eds. Bernhart Walter and Werner Wolf (Leiden: Brill, 20I8), I27-I52. Similar categories and distinctions are formulated by Irina O. Rajewsky, "Border Talks: The Problematic Status of Media Borders in the Current Debate about Intermediality," in Media Borders, Multimodality and Intermediality, ed. Lars Elleström (Basingstoke: Palgrave Macmillan, 20I0), 5I-68; Irina O. Rajewsky, "Intermediality, Intertextuality, and Remediation," Intermediality: History and Theory of the Arts, Literature and Technologies, no. 6 (2005): 43-64. See also Christer Johansson and Sonya Petersson, "Introduction," in The Power of the In-Between: Intermediality as a Tool for Aesthetic Analysis and Critical Reflection, eds. Sonya Petersson et al. (Stockholm: Stockholm University Press, 20I 8), I-2I.

5 Wolf, “The Relevance of Mediality and Intermediality," I 27-I 52. 
moving images, occasional expositions of websites, and the viewers' written commentaries in the YouTube comment sections and in live chatrooms. The podcast episodes are instances of intracompositional, plurimedial intermediality, that is, composites of images and sounds, two media materially present in one configuration. This intracompositional intermediality, moving images and synchronized sound, is of course highly conventional, to the point of being considered a medium in its own right, and could thus be thought of as an instance of intermedial fusion, perhaps the dominant one (except for the internet itself) at this point in time of media history. The occasional presence (in the form of mimetic representations) and discussions (thematizations of sorts) of websites, themselves intermedial interreferences, combinations, and fusions, and the written messages of the comment sections, have a quality of indirectness. The latter functions as intermedial references to other digital objects and to the primary digital object (the present audiovisual podcast episode), respectively, rather than being part of the intracompositional intermediality. The podcast episodes thus not only are audiovisual intermedial combinations but also contain intermedial references to various websites and are the targets of intermedial references by way of written commentaries, thus including the viewers, and their interactivity, in the shows. This description is probably valid for many or most "talk shows" on YouTube and other similar video-sharing websites.

A different but related way to approach media relations and media compounds is, following W. J. T. Mitchell and Lars Elleström, to analyze them by means of the multimodal conception of mediality, less based on formal typologies and more focusing on the role and function of sensory, perceptual, and interpretative interaction with media. ${ }^{6}$ According to Mitchell, a medium and its mediation

${ }^{6}$ W. J. T. Mitchell, "There Are No Visual Media," Journal of Visual Culture 4 (2005): 257-266; Lars Elleström, ed., "The Modalities of Media: A Model for Understanding Intermedial Relations," in Media Borders, Multimodality and Intermediality (Basingstoke: Palgrave Macmillan, 20I0), I I-48. For a related, practical, application of "synesthetic prototyping" in digital recreations of ancient soundscapes, see Anna Foka and Viktor Arvidsson, "Experiential Analogies: A Sonic Digital Ekphrasis as a Digital Humanities Project," Digital Humanities Quarterly ıо, no. 2 (20I6): paragraphs $1-50$. 
always entail some mix of the sensory, perceptual, and semiotic elements. All media are necessarily approached by the senses (sight, hearing, touch, etc.) and prompted by "semiotic operators," such as the Peircean triad of iconic (based on similarity), indexical (based on contiguity), and symbolic (based on conventionality) signs. ${ }^{7}$ Mitchell's point is that all media are "mixed media," but not "mixed in the same way." "Elleström's multimodal concept follows and elaborates the logic of Mitchell's: four "modalities" are understood as present in all media, but in different ways, to different degrees, and in different combinations. Elleström distinguishes between "the material modality," "the sensorial modality," "the spatiotemporal modality," and the "semiotic modality." The sensorial modality regards the physical and mental acts of perceiving the medial interface, and the material modality includes the "latent corporeality of the medium," whereas the spatiotemporal modality covers "the structuring of the sensorial perception of sense-data of the material interface into experiences and conceptions of space and time." ${ }^{\text {} 0}$ The material interfaces condition sensory inputs, which give rise to perceptions that are structured in space and time and understood as signifying.

So, how should the multimodal mix of the podcasts be described? The material modality, to begin with, has a quality characteristic of many podcasts today: it consists of two different digital versions posted on different internet platforms. The Joe Rogan Experience and Hur kan vi? are published on a number of platforms: on YouTube as filmed audiovisual shows, including sound and image tracks, and on other platforms, such as Acast, iTunes, and Spotify, as audio files. The materiality of these shows are thus of two different kinds: the one multimedial (consisting of two different basic media, audiotext and moving images), the other monomedial (consisting of one basic media, audiotext), which means that the combination of images and sounds could not, in

7 Mitchell, "There Are No Visual Media," 26r; Charles S. Peirce, "Logics as Semiotic: The Theory of Signs," in Semiotics: An Introductory Anthology, ed. Robert E. Innis (Bloomington, IN: Indiana University Press, I985), I-23.

${ }^{8}$ Mitchell, "There Are No Visual Media," 260.

9 Elleström, "The Modalities of Media," I7-24.

ro Elleström, "The Modalities of Media," I 8. 
this case, be considered an intermedial fusion but a combination where the channels are possible to separate. This situation has obvious implications for the "the sensorial modality." The YouTube versions of the shows engage both hearing and sight, while the audio versions only engage the former sense. This fact, in turn, has implications for the spatiotemporal modality of the podcasts, as the spatial location is implicit in the audio versions, while the dimension of time is central in both versions. From these observations we can conclude that, in the multimodal mix, the soundtrack and hearing, and the temporal mode are superordinate to the image track, sight, and space. Otherwise, it would not make sense to publish the podcast episodes without the image track. An investigation of the semiotic modality seems to confirm this interpretation. Of central importance are the spoken words, conventional signs amplified by facial expressions and body language, that is, a combination of indexical and iconic signs. The most important iconic aspect is, however, a temporal one. The recorded conversations air uncut as they evolve, as temporal continuities, without any deletions. The episodes of The Joe Rogan Experience and Hur kan vi? could thus be described as a sort of diagrammatic icons, the temporal order and duration of the actual conversation coinciding with the temporal order and duration of the episode. ${ }^{\text {II }}$ All in all, indexical and iconic sign relations are, it could be argued, in service of the conventional signs of the spoken word.

In conclusion, an intermedial and multimodal analysis indicates, on the one hand, that the podcasts here are typical contemporary YouTube instances of intracompositional, plurimedial combinations (audiotext and moving images) referencing other parts of the internet and being commented on. On the other hand, the analysis indicates that the medial components, partly due to the diversification of the materiality of the episodes, are differently weighted: sound is more important than image, hearing more important than sight, time more important than space, and conventional linguistic signs more important than indexical and iconic sign relations. ${ }^{\mathrm{I} 2}$

\footnotetext{
II Peirce, "Logic as Semiotic."

${ }^{12}$ For more on YouTube as multimodal text see Phil Benson, The Discourse of YouTube: Multimodal Text in a Global Context (New York: Routledge, 2OI7).
} 
A rather obvious interpretation of the constitution of this multimodal complex is that, among all media, modalities, and modes, the spoken word, oral communication and dialogue, takes pride of place in the multimodal mix. This brings us to another dimension of the intermedial/multimodal analysis, put on hold until now, namely the distinction between mediation and transformation. These terms designate the fact that sometimes, or perhaps most of the time, the content of one medium is another medium. The other medium is in some cases mediated, that is, represented without the loss of essential modal qualities, in other cases transformed, that is, changed as a consequence of differences between the signifier of the transforming medium and the qualities of the medium being transformed. ${ }^{\mathrm{I} 3}$ We could argue, I believe, that the podcasts mediate oral dialogue, even though the audio version is a less rich mediation, lacking the visual dimension. When listening to the podcast episodes we are actually listening to the conversations between the hosts and their guests, and when watching the YouTube shows the image tracks contribute, by way of iconic and indexical representations, additional information to the context of the dialogue. The relations between the podcast episodes as representations and the mediated dialogue are, however, I will argue, more complicated, demanding the introduction of yet another concept: remediation, which is always a transformation. Remediation is compatible with the concepts of intermediality and multimodality, as it designates relations between media, but by making use of this concept we leave the formal analysis of intermediality studies, and enter the domain of media-historical explorations.

\section{Media History as Remediation: The Refashioning of the Radio and Televison Talkshow}

Inspired by Marshall McLuhan, in the late '9os David Bolter and Richard Grusin coined the term "remediation" to describe a kind of intermedial relationship in which both old and new media, by way of processes of medial refashioning, are involved

${ }^{13}$ Lars Elleström, Media Transformation: The Transfer of Media Characteristics Among Media (Basingstoke: Palgrave Macmillian, 20I4), I 2-35. 
in "competition or rivalry," and struggling for cultural status, either through "immediacy" (concealing media) or through "hypermediacy" (foregrounding media). Remediation is thus, Bolter and Grusin argue, a "defining characteristic" of digital media and, at the same time, a fundamental characteristic of all medial practices. $^{\mathrm{I} 4}$

It is my contention that podcast shows such as The Joe Rogan Experience and Hur kan vi? not only mediate oral dialogue but also remediate and transform the medium of radio and, more specifically, the genre of the radio talk show. When watching The Joe Rogan Experience on YouTube, it is obvious that the images show us the interior of something akin to a radio studio, a studio designed for the recording of spoken dialogue. The full shots represent a studio with red brick walls, an American flag on the wall behind Joe, always situated to the left, and a dark velvet curtain on the wall behind the guest(s), always to the right. The studio also contains some gadgets and water bottles on the table between the host and the guest, heavy microphones on tripods, big earphones on the host and the guests, and, in the foreground, a digital mixer on a computer screen. The show mainly consists of shot/reverse shot sequences, following the dialogue, representing the speaker in close-up shots (the microphones held by microphone arms and the headphones being prominent), now and then replaced by full shots showing both host and guest(s), as well as the interior of the studio.

Hur kan vi? is modeled after the patterns of The Joe Rogan Experience, and the basic structure is the shot/reverse shot sequences, representing the dialogue, as described above. But the Swedish show also differs from the original. With the exception of some of the early shows, the full shots are lacking, and the headphones are optional: sometimes they are used by all involved, sometimes neither host nor guest have them on, and sometimes the host wears them while the guest does not, and, in the latest version of the show, the headphones are no longer used. In general, the radio studio connotations are less emphasized in Hur kan $v i$ ? , and the episodes are shot in various premises (in the latest

${ }^{14}$ Jay David Bolter and Richard Grusin, Remediation: Understanding New Media (Cambridge: MIT Press, I999), 45, 70-72. 
version of the show there is a new studio with partly different connotations; for more on this, see below). In both shows, the recording process as such is referred to every now and then, by the host or by both host and/or guests, and the big microphones are adjusted for the sound level to be optimal. So, both podcasts are, to an extent, remediating and sometimes even thematizing radio and the sound recording studio as media. Perhaps there is a predecessor in the Howard Stern Show, a radio show that early on combined radio and TV, filming the events in the studio, to this day posting clips from the radio show on YouTube and the SiriusXM app. ${ }^{\text {I5 }}$ Joe Rogan has himself identified the radio comedy talk show Opie and Anthony as his most important influence, stating that it was the lack of structure and the improvisation that he found interesting. ${ }^{16}$

Remediations are, however, never just recreations of older media and media situations but also transformations of the remediated media patterns, challenging the other medium. Consequently, the YouTube podcasts do things that conventional radio does not. The filming of the conversations and the studio, the combination of image and soundtrack, is of course the most obvious transformation. Another difference between radio talk shows and the podcasts is the fluid time format. In distinction to conventional, linear radio, the podcast episodes lack a standardized duration, and are usually much longer than the typical radio show, from one to over four hours. The duration of the conversations determines the duration of the episodes, not the other way around.

In addition to this, and analogous to the radio case, the podcasts could be viewed as remediations of the genre of the television talk show. We all know the pioneering ones like The Tonight Show

is For more on the Howard Stern Show, see the Howard Stern website, https://www.howardstern.com.

16 Opie and Anthony is an American radio show cohosted by Gregg "Opie" Hughes and Anthony Cumia that aired from I 995 to 20I4, with comedian Jim Norton serving as third mic beginning in 200I. For more information on the show, see Internet Archive website, "Opie and Anthony Radio Show Archive," https://archive.org/details/opieandanthonyarchive?tab =about; Joe Rogan on the Opie and Anthony show: "Joe Rogan on the Influence of Opie \& Anthony," YouTube, December 6, 20I 7, https://www

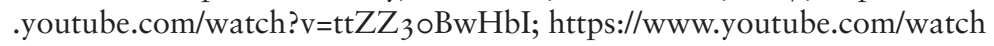
?v=yXZn2DkrXig. 
(1954-) in the USA, and Hylands hörna (I962-83) in Sweden. ${ }^{17}$ As in the traditional talk shows, there are hosts and one or more guests in the podcasts and the conversations are focused on the guests, as persons and professionals. ${ }^{18}$ That being said, the podcast shows under scrutiny differ more from television talk shows than they resemble them. There are no house bands, no live audiences (except for the Hur kan vi? live events), and, more importantly, no interviews and, again, no time limits or predetermined segments. The hosts do not interview their guests; what we experience are spontaneous conversations between (more or less) equals. A case in point is a recent $J R E$ episode $\left(\#_{\left.\mathrm{I}_{4} \mathrm{I}_{3}\right)}\right.$ ) guested by Bill Maher, a fellow comedian, political commentator, and television host for HBO show Real Time with Bill Maher. ${ }^{19}$ The episode is thus a meeting, and confrontation, between the old format of the political talk show and the new format of the long-form conversation podcast. At the beginning of the episode the two hosts/comedians discuss whether Bill feels constrained by the hour format of his show and he arrives at the conclusion that conversations of the kind they are about to have "lend themselves [...] to just letting it happen," and we learn that neither the host nor the guest has prepared for the show. What we then experience is thus an almost two-hour-long, spontaneous, unscripted, conversation. ${ }^{20}$

In the latest version of Hur kan vi?, the headphones are gone, and the studio is now designed to be viewed, with a round coffee

${ }^{17}$ For more on the talk show as genre, see Wayne Munson, All Talk: The Talkshow in Media Culture (Philadelphia, PA: Temple University Press, I993).

I8 It could be argued that YouTube is, together with subscription-based streaming services such as Netflix and $\mathrm{HBO}$, about to replace traditional, linear television, and that shows such as The Joe Rogan Experience and Hur kan vi? are part of that shift. Notice that YouTube is also a remediation of the video player. For more on YouTube and television, see The YouTube Reader, eds. Pelle Snickars and Patrick Vonderau (Stockholm: National Library of Sweden, 2009); on YouTube and interactivity, see Jean Burgess and Joshua Benjamin Green, YouTube: Online Video and Participatory Culture (Cambridge: Polity, 2009).

19 For more information on Real Time, see "Real Time with Bill Maher," You Tube, https://www.youtube.com/channel/UCy6kyFxaMqGtpE3pQTflK8A.

${ }^{\circ}$ The Joe Rogan Experience, "Episode \#I4I3 - Bill Maher," You Tube, January I7, 2020, https://www.youtube.com/watch?v=-KQGZa773sI. 
table with cups and a water bottle, two visible armchairs, and a lot of gadgets in the shelf in the background, showed in wider shots than in the previous seasons. On the first show after the summer break, the host Navid Modiri refers to the new studio, comparing it to a well-known Swedish "experimental" television talk show in the past, Knesset at ZTV, which ran between I995 and I997. ${ }^{21}$ "Punk" television is now explicitly appropriated and remediated, and transformed, following the patterns of The Joe Rogan Experience as described above.

To summarize, The Joe Rogan Experience and Hur kan vi? remediate radio as a medium and the radio talk show as a genre. The shows even include a discreet metalevel concerned with the recording process, the studio, and the recording equipment. At the same time, the image track, showing the recording situation, and the extended, variable duration of the episodes are transformations of the radio medium beyond its conventional limits. The same is, to a lesser extent, true of television as a medium and the televised talk show as a genre. The remediation transforms the traditional television format into a spontaneous, unscripted conversation.

\section{Media History and the (New) Oral Paradigm}

Another way to approach the historical aspects of the podcasts here is to relate them to the medium of writing and the media landscapes of the past and the present. The founding scholars of media-historical research, such as Jack Goody, Eric Havelock, Marshall McLuhan, and Walter Ong, investigate the domain of orality, its relation to writing, and, more generally, the relationship between communication, technology, and society. ${ }^{22}$ Let us explore

2г “Ztv Knesset," YouTube, https://www.youtube.com/channel/UCFbXd DDRFogVAnPt2cFr-bA/videos.

${ }_{22}$ Marshall McLuhan, Understanding Media: The Extensions of Man, critical ed. (Corte Madera: Ginko Press, 2003 [I964]); Jack Goody, Myth, Ritual and the Oral (Cambridge: Cambridge University Press, 2010); Eric Alfred Havelock, The Muse Learns to Write: Reflections on Orality and Literacy from Antiquity to the Present (New Haven, CT: Yale University Press, I986); Walter J. Ong, Orality and Literacy: The Technologizing of the Word (London: Methuen, I982). For criticism of these approaches see Jan Assmann, Cultural Memory and Early Civilization: Writing, 
what this early research on the spoken word and oral culture can tell us about the new orality of long-form conversational podcasts like The Joe Rogan Experience and Hur kan vi?

Ong argues that the characteristics of the oral world, before writing, are that it is "formulaic," conservative, "close to the human world," "agonistically toned," empathetic, homeostatic, situational, communal, and involves memorization by formula rather than verbatim. The literate world is the opposite to all of these things, as it is abstract, analytic, distancing, objective, and separative. ${ }^{23}$ These differences can be derived from the qualities of the media involved: the existence of sound is volatile, always in process; marks on visual, external surfaces, that is, writing, are isolating, dissecting, analytical, and fixed in a way that sound is not. Owing to the basic differences between sound and vision, the advent of literacy leads to the development of a new and different consciousness. Writing enables a shift from a prelogical to a logical mentality: the distinction of myth from history, the development of science, objectivity, critical thought, and abstraction. ${ }^{24}$ Similar thoughts are formulated by Goody and Havelock.

According to McLuhan, there is a struggle between orality and literacy, reinforced by printing, and between tribal man and literal man. McLuhan detects a break between "the auditory and the visual experience of man." Only the phonetic alphabet makes such a sharp division in experience possible, "giving to its user an eye for an ear, and freeing him from the tribal trance of resonating word magic and the web of kinship." ${ }^{25}$ Man's development from tribal to literate means that he is "emotionally free to separate from the tribe and to become a civilized individual, a man of visual organization who has uniform attitudes, habits, and rights with all other civilized individuals.” ${ }^{26}$ The Western world is homogenized, through segmentation and repeatability, McLuhan argues. ${ }^{27}$

Remembrance, and Political Imagination, Ist English ed. (Cambridge:

Cambridge University Press, 20I I).

23 Ong, Orality and Literacy.

${ }_{24}$ McLuhan, Understanding Media, 30, 33, I 8.

25 McLuhan, Understanding Media, I 20.

${ }_{26}$ McLuhan, Understanding Media, I 18.

27 McLuhan, Understanding Media, 75, 237, 237, 239. 
However, this also means that man is fragmented; writing, and printing, extends the human mind but at the same time dissociates senses and faculties. ${ }^{28}$ Printing, the mechanization of the word, consolidates this development; there is a typographic explosion of the consciousness of the human mind. ${ }^{29}$ Tribalism and the clan are exploded by printing..$^{\circ}$

This balance between speech and writing is changed by the, in McLuhan's terms, electric technology:

The alphabet (and its extension into typography) made possible the spread of the power that is knowledge, and shattered the bonds of tribal man, thus exploding him into an agglomeration of individuals. Electric writing and speed pour upon him, instantaneously and continuously, the concerns of all other men. He becomes tribal once more. The human family becomes one tribe again. ${ }^{31}$

Because of its extension of our central nervous system, electric technology (the media of telephone, radio, and TV), McLuhan argues, seems to favor the inclusive and participational spoken word over the specialist written word. ${ }^{32}$ McLuhan's description dovetails with Ong's concept of "secondary orality." Secondary orality is dependent on literate culture and the existence of writing, manifested, for example, in the phonograph and radio, and it is a "a more deliberate and self-conscious orality." 33

Long-form conversation podcasts like The Joe Rogan Experience and Hur kan vi? could and should thus be analyzed as a form of secondary orality, with deep roots in primary orality. They could be viewed as a continuation and an updated version of the orality characteristic of the electric age of radio and television, as described by McLuhan. The consciousness of the podcasts has, it could be argued, many of the characteristics of orality pointed out by McLuhan. The podcasts are, on the one hand, empathetic,

${ }_{28}$ McLuhan, Understanding Media, I I 4, I 20.

29 McLuhan, Understanding Media, 233.

30 McLuhan, Understanding Media, 240.

31 McLuhan, Understanding Media, 234.

${ }^{32}$ McLuhan, Understanding Media, I I 7; cf. 21, 65, 70, 75, 235-236.

33 Ong, Orality and Literacy, I33; cf. Walter J. Ong, Rhetoric, Romance, and Technology: Studies in the Interaction of Expression and Culture (Ithaca, NY: Cornell University Press, I97I). 
situational, communal, inclusive, and participational; on the other, volatile and processual. And perhaps podcasts, like the ones under scrutiny, finally realize McLuhan's dream of the retribalization of man.

There is a sense of enhanced community to these projects, and perhaps a tribal (in McLuhan's sense of the word) quality. Both The Joe Rogan Experience and Hur kan vi? are all about the inclusive and participational spoken word, and their respective hosts try to bond with all kinds of people interested in expressing themselves and enter the dialogue. They talk to everyone, from left to right. They invite the politically incorrect: the conspiracy theorists, the controversial, the crude, and the crazy. All and everyone are part of the tribe and worth listening to, seems to be the attitude. And, so, Alex Jones from Infowars, democratic socialist Bernie Sanders, leftist journalist Abby Martin, philosopher and political activist Cornel West, and left-wing political pundit and academic David Pakman, as well as conservative political commentator Ben Shapiro and professor of psychology and libertarian Jordan Peterson participate in different episodes of Joe Rogan's podcast. The same is true of Hur kan vi?, inviting alternative journalist and libertarian Chang Frick, conceptual artist and activist Lars Wilks, and right-wing activist Ingrid Carlqvist, as well as investigative journalist Janne Josefsson, left leaning comedian Henrik Schyffert, left-wing politician Amineh Kakabaveh, and the former leader of the Swedish Left Party and spokesperson of Feminist Initiative Gudrun Schyman. The Joe Rogan Experience and Hur kan vi? could thus be interpreted as cultural projects attempting to recreate the lost tribalism of "written," digitalized culture, trying to involve all kinds of deviant voices in the ongoing dialogue.

More importantly, the podcasts seem to constitute part of a counterculture to important aspects of digital mainstream culture. Much of what McLuhan thought was characteristic of literacy and the culture of writing could be used as a description of the effects of the digital platforms and social media of today, especially fragmentation and segmentation, a sense of isolation and distance. This is true of Facebook and Instagram, blogs, vlogs and Twitter, internet forums and comment sections, Snapchat, and memes, as well as of emails and SMS. These media are all, in one 
way or another, remediations of text types, written genres and linguistic phenomena (the book, the diary, the telegram, the log, the letter, written commentary, the lexeme, mimesis, and so on) extending the human mind and connecting people. At the same time, the mediated messages are brief, functioning as vehicles of short information and/or self-expression, leaving no room for elaborate conversations. Podcasts like The Joe Rogan Experience and Hur kan vi? can be construed as attempts to be an alternative to the briefness and fragmentation of much of internet culture, giving precedence to continuity. Both podcasts promote hour-long, improvised conversations. The agents involved in the conversation are present to each other and the sense of presentness is, as we have seen, enhanced through the uncut, live format (either live proper or live-on-tape), and through an in medias res quality, as if we as viewers or listeners were thrown into an already ongoing conversation. The Joe Rogan Experience usually starts with the host, Joe Rogan, announcing that the live feed has begun ("And boom, we're live"), or with the guest and/or the host already talking over the rotating vignette (an image of Joe Rogan with a third, all-seeing eye), fading out, and giving way to the moving images showing the interior of the studio. The Hur kan vi? episodes sometimes start mid-conversation, without the guests being aware that the show has begun. ${ }^{34}$

To these early media historians, I would like to add the recent observations of media philosopher John Durham Peters, who has investigated the function of the written word in our digital era, and how it relates to orality. Peters observes that the "written word is one of the clearest historical continuities between early civilization and the latest innovations." New social media takes us back, Peters argues, to the beginnings of distant interaction. And he continues: "digital media, whatever else they are, are machines that convert everyone into writers." 35 In the digital era we are all potential writers, and the original questions of the relations

${ }^{34}$ Hur kan vi?, "Episode \#69: Janne Josefsson - Jag dör om jag slutar jobba," YouTube, June 30, 2019, https://www.youtube.com/watch?v $=$ ZwSBoglx6RU.

35 John Durham Peters, The Marvelous Clouds: Toward a Philosophy of Elemental Media (Chicago, IL: University of Chicago Press, 201 5), 264, 
between flesh and word, presence and absence, are once again updated..$^{36}$

The absence characteristic of writing comes with certain benefits that face-to-face communication does not provide. To begin with, as Peters observes, "[ $\mathrm{t}]$ ext messaging, Twitter, and Facebook, like earlier forms of writing, suspend the risks of real time." ${ }_{77}$ The medium of writing offers us a parallel world to the serial universe of face-to-face talk. In online posts and comments, people have time to work on their profiles and presentations, and can thus appear a little better, a little more interesting. Peters continues: "As Plato complained, writing can serve as a performance-enhancing drug; you always get a second chance. On Facebook, everybody gets to be Oscar Wilde." ${ }^{8} 8$ The interaction on social media also provides a bodiless and/or anonymous presence, allowing for behavior beyond the social contract in everyday situations. According to Peters, online interaction reduces "emotional bandwidth." In text messages, you do not have to decide whether to identify yourself, or behave politely. A text message is, Peters explains, decapitated and legless: "Online interaction changes the recipe by seemingly taking the body out of the equation and scrambling the rules of animal behavior." 39 So-called "trolls" and harassers can get away with sociopathic behaviors online that would be hard to do elsewhere. Peters continues: "The online world breeds styles of maliciousness that seem perversely fitted to the narcissism and solitude of the act of writing, something that obeys laws very different from those of orality. Writing takes its revenge in the age of digital media." ${ }^{\circ}$ Therefore, Peters seem to imply that the social media of today foster behaviors closely connected to, and perhaps made possible by, the medium of writing:

The Internet is a breeding ground for fantasy bodies, "one big orgy, an endless informational bacchanal” for memes, spam, porn,

265. Peters does not share McLuhan's nostalgic approach to the oral past, 264 .

${ }^{6}$ Peters, The Marvelous Clouds, 266, 273.

37 Peters, The Marvelous Clouds, 273.

${ }^{38}$ Peters, The Marvelous Clouds, 274.

39 Peters, The Marvelous Clouds, 275.

4० Peters, The Marvelous Clouds, 275. 
and their human hosts-a destructive, volatile zone not at all the safe, happy place that the Internet companies paint it to be. In this way, it is like an older habitat, writing. ${ }^{4}{ }^{\mathrm{T}}$

It is, once again, my contention that the podcasts under scrutiny are developed, more or less consciously, in relation to this new form of writing. Unlike the written social media of our time, the podcasts elaborate, work with, the risks of real time: the clock never stops; you have to perform on the spot, a quality enhanced by the lack of script and the reluctance to edit the episodes. It is exactly writing's possibility to stall time and hide our faces, voices, and identities, so typical of social media like Twitter and Facebook, that the podcasts try to abolish. The Joe Rogan Experience and Hur kan vi? have the ambition to simulate face-to-face communication in real time, to make the presence of human bodies felt. The risks and social anxieties of conversations, pointed out by Peters, are embraced by the podcast shows. Considered from a historical perspective, the podcasts here could be described as anti-writing, if by writing we mean modern social media's exploration of the medium. Just as electronic media could be understood in relation to writing, long-form conversation podcasts can be understood in relation to social media.

Finally, alongside the tribalism 2.0, or perhaps 3.0, the podcasts seem to promote some of the qualities of writing highlighted by researchers such as Goody, Havelock, and Ong. Writing and literacy are, as we have seen, strongly associated with abstraction, analyticity, and critical thought, elements essential to the conversations of The Joe Rogan Experience and Hur kan vi? The consciousnesses fashioned by these podcasts are thus very much the products of literacy, or perhaps the perfect illustration of the concept of secondary orality, in the sense of a more deliberate and self-conscious orality. One last comment is appropriate. The broadcasting on YouTube means that the channels of The Joe Rogan Experience and Hur kan vi? have another quality typical of writing: they are living archives for audiovisual text. Transmission and preservation are colliding.

${ }^{41}$ Peters, The Marvelous Clouds, 277. 


\section{Media as Infrastructure and the Bias of Communication: A Synchronic Analysis}

I will end this chapter by applying a communication-theoretical perspective to The Joe Rogan Experience and Hur kan vi?, a perspective that, paradoxically, transcends the phenomenon of communication proper. My ambition is to sketch a synchronic analysis of the media infrastructure constituting the conditions for both podcasts.

In current media theory, as formulated by W. J. T. Mitchell, Mark B. N. Hansen, and John Durham Peters, among others, "medium" is not only considered a semiotic, representational, and communicative phenomenon but something even more fundamental, permeating both nature and culture, the semiotic as well as the nonsemiotic. This environmental media concept enables a contextualizing interpretation of modes and media as agents and infrastructures. ${ }^{42}$ In this context, I would like to single out one aspect of the infrastructural understanding of media, as it is formulated by Peters, Friedrich Kittler, and especially Harold Innis. Kittler coins the concept of the "Schriftmonopol," or monopoly of writing, ${ }^{43}$ explained by Peters, referencing Innis, in the following way:

Historically, priests, scribes, scholars, and bureaucrats have had little incentive to make writing technology more accessible. Barriers to entry, as Innis would remind us, aid monopoly control, and the history of writing is not only a succession of scripts but a struggle between groups for control over the means of communication. ${ }^{44}$

For Innis, the focal point of interest is the analysis of politics and power in relation to media. ${ }^{45}$ His most important concept,

${ }^{42}$ W. J. T. Mitchell and Mark B. N. Hansen, eds., "Introduction," in Critical Terms for Media Studies (Chicago, IL: University of Chicago Press, 2010), vii-xxii.

43 Friedrich A. Kittler, Gramofon. Film. Typewriter (Berlin: Brinkman and Bose, I986), I 2.

44 Peters, The Marvelous Clouds, 296-297.

45 Harold A. Innis, The Bias of Communication (Toronto: University of Toronto Press, I95I); Harold A. Innis, Empire and Communications (Toronto and New York: Dundurn Press, 2007 [I950]); Edward Comor, "Harold Innis and 'The Bias of Communication," Information, Communication \& Society 4, no. 2 (2001): 274-293, 277, 282. 
formulated in his seminal works on media and communication theory, The Bias of Communication and Empire and Communications, is "media bias," or, more precisely, "the "biases' of core institutions, organizations and technologies-the nodal points through which what we know and how we know are produced and reproduced." ${ }^{6}$ Innis's work offers a model for the conceptualization of a struggle involving not only time, space, and the temporal or spatial biases of dominant media but also control over knowledge, wealth, and force. Innis views history as the dialectics of "'monopolies of knowledge' and 'monopolies of power'." Monopolies of knowledge means those interests that control access to information, or those interests that has the dominant influence on patterns of social habits and conceptions. ${ }^{47}$ Innis's model constitutes a means of assessing potential developments involving how changing media environments affect power relations. ${ }^{48}$ In the following, I will focus on the control over knowledge, wealth (here interpreted as economic infrastructure), and force (here interpreted as a struggle within the political sphere), which I consider important parts of a digital human sciences method for analyzing internet culture. 49

Knowledge, to begin with. It is obvious that digital media platforms like YouTube have changed the dynamics of knowledge production in countries like the USA and Sweden. Former monopolies of knowledge, controlling dominant ways to perceive and think, have been challenged. The medial infrastructure is in a state of transformation. This is true of traditional mass media and of educational institutions. The Joe Rogan Experience and Hur kan $v i$ ? publish intellectual content independent of these traditional institutions, directly reaching their audiences, large in numbers. The former show has, at this point, more than 7.5 million subscribers on YouTube and many episodes have over a million views; some shows tens of millions of views. Hur kan vi? has 23,300 subscribers, most episodes have tens of thousands of views and some episodes over a hundred thousand views. Both hosts, Joe Rogan and Navid Modiri, have pasts in mainstream media,

${ }_{46}$ Comor, "Harold Innis," 276.

47 Comor, "Harold Innis," $28 \mathrm{I}$.

$4^{8}$ Comor, "Harold Innis," 284.

49 Comor, "Harold Innis," 284. 
Joe Rogan (besides being a stand-up comedian) as a sports commentator and television host, Navid Modiri as a radio and television host, and criticism directed at established knowledge institutions is a theme running through both podcasts. In Hur kan vi?, discussions of the problematic status and bias of Swedish public service radio and television and its relation to freedom of speech and democracy are, for example, central topics in episodes with author and satirist Jens Ganman, stand-up comedian and podcast host Aron Flam, and investigative journalist Janne Josefsson..$^{\circ}$ The Joe Rogan Experience has become part of the so-called Intellectual Dark Web, ${ }^{\text {I }}$ a group of public personalities at some point being silenced, marginalized, and even purged from institutions hostile to deviant thoughts, in the media and academia..$^{52}$ Dominant figures in this loosely composed group are neuroscientist Sam Harris; the evolutionary biologists Bret Weinstein and Heather Heying; Eric Weinstein, a mathematician and managing director of Thiel Capital; Jordan Peterson, the psychologist and bestselling author; the conservative commentators Ben Shapiro and Douglas Murray; and the feminists Ayaan Hirsi Ali and Christina Hoff Sommers. The core members have little in common politically; their preferences belong all over the political spectrum. The question of free speech, political correctness, and the dangers of identity politics are frequent topics when one or several IDW members visit the Joe Rogan Experience podcast. Whatever the topic, the IDW members agree on the importance of conversation, on the possibility of disagreeing without hostility, and of favoring facts before feelings. The podcast has also had James A. Lindsay and Peter Boghossian as guests, the men behind the "grievance studies affair," highlighting what they considered to be poor scholarship

5० Hur kan vi?, “Episode \#8: Aron Flam - 'Vi är slavar för staten,'” YouTube, July 8, 20I 8, https://www.youtube.com/watch?v=UarNWZgzcXc; Hur kan vi?, "Episode \#II: Jens Ganman - 'Vi lever i en värld där media vrider på verkligheten," 'YouTube, July 22, 20I 8, https:/www.youtube .com/watch?v=KZB 7 SOOJ3wE; Hur kan vi?, "Episode \#69: Janne Josefsson - Jag dör om jag slutar jobba,” YouTube, June 30, 20I9, https:// www.youtube.com/watch?v=ZwSBoglx6RU.

${ }_{51}$ "Joe Rogan on Being in the Intellectual Dark Web," YouTube, July 26, 20I 8, https://www.youtube.com/watch? v=spb8bYIfP Ig.

$5^{2}$ For more information, see Intellectual Dark Web website, https://intellec tualdarkweb.site/vanguards-of-the-intellectual-dark-web. 
in several academic fields. Their project consisted of submitting bogus academic papers to academic journals in cultural, queer, race, gender, fat, and sexuality studies to determine if they would pass through peer review and be accepted for publication (which several of these papers were). ${ }^{53}$

Both podcasts have been debated on Twitter and in other social media, as well as in traditional media. The Hur kan vi? podcast has been contested in traditional Swedish media, especially after the appearance of right-wing extremist Ingrid Carlqvist on January 27, 20I9, Holocaust Memorial Day. ${ }^{54}$ The day of the release was, according to Modiri, a mistake. The episode, however, became the subject of vigorous debate. Navid Modiri was criticized, in Swedish newspapers like Arbetet, Expressen, and Sydvenskan, for being much too uncritical of the controversial guest, and for trivializing the Holocaust. ${ }^{55}$ In interviews in the Swedish magazines Resumé and Dagens Media, and the newspaper Svenska Dagbladet, Modiri says the main goal of the podcast episode is the same as the podcast as a whole: to contribute to a more open climate of discussion where a wider range of opinions could be expressed. This means listening to antagonists, challenging opinions, and talking to people we find annoying. The show's goal is to make people with different opinions talk to each other, as is evident during the Hur kan vi? live events. All dialogue and

${ }_{33}$ The Joe Rogan Experience, "Episode \#II9I: Peter Boghossian \& James Lindsay," YouTube, October 30, 20I 8, https://www.youtube.com/watch? v=AZZNvTrvaJg; "The Grievance Studies Affair,” YouTube, last updated April 23, 20I9, https://www.youtube.com/playlist?list=PLLHyNSlsz44 -mMSAXVWXjwRc8KOlA8Vrg.

${ }^{54}$ Hur kan vi?, "Episode \#44: Ingrid Carlqvist - 'Hijaben används för att män ska få veta vilka kvinnor som får våldtas," ' YouTube, January 27, 20I9, https://www.youtube.com/watch?v=yLLj2YMwiRM.

55 Kolbjörn Guwallius, "Modiris podd om Förintelsen är ett fullständigt haveri,"” Arbetet, January 29, 20I9, https://arbetet.se/20I9/OI/29/modiris -podd-om-forintelsen-ar-ett-fullstandigt-haveri; Dan Korn, "Det fria samtalet har en gräns, Navid Modiri," Expressen, February I4, 20I9, https://www.expressen.se/kultur/ide/det-fria-samtalet-har-en-grans -navid-modiri; Ida Ölmedal, "Navid Modiri och högerextremismen," Sydsvenskan, February 3, 20I9, https://www.sydsvenskan.se/20I9-02-03 /navid-modiri-och-hogerextremismen; Andreas Ekström, "Navid Modiris podd är ansvarslös," Sydsvenskan, January 30, 20I9, https://www .sydsvenskan.se/20I9-OI-3o/navid-modiris-podd-ar-ansvarslos. 
discussions should be acceptable, we should be able to talk to everybody about every- and anything, even Norwegian terrorist Anders Behring Breivik. This is what democracy and freedom of speech are all about, and a prerequisite for a collaborative society. ${ }^{56}$ Modiri also stresses that Hur kan vi? is something new and different, and that the podcast team is trying to understand what it is. It is not public service, and not traditional journalism, but instead some kind of popular adult education.

This debate is basically about how media should function, and about the difference between new media forms such as the podcasts here and more traditional media outlets. Two different models, directly related to Innis's ideas on monopolies of knowledge, are played out against each other: on the one hand, the conversation activists, trying to fight polarization and radicalization with inclusion; on the other hand, the traditional media strategy using gatekeepers/publishers to decide what debates are worth having.

The discourse surrounding The Joe Rogan Experience is similar to the one surrounding Hur kan vi? The most important debate concerns the lack of a gatekeeping function. Joe is accused of not being critical enough when interviewing guests such as Elon Musk or Milo Yiannopoulos; he is not behaving like an investigative, critical journalist but as a conversation partner, and he talks to everybody he finds interesting, including people not welcome in mainstream media, right-wing profiles, and tricksters of different kinds, often challenging political correctness and using satire to make fun of contemporary phenomena. Rogan is a free speech absolutist, and he, and his guests, are sometimes drinking and smoking weed during the shows, which is likely to weaken the

\footnotetext{
${ }^{6}$ Andreas Rågsjö Thorell, “Navid Modiri svarar på kritiken: 'Ett olyckligt och stort misstag," Resumé, January 3 I, 20I9, https://www.resume.se /kommunikation/media/navid-modiri-svarar-pa-kritiken-ett-olyckligt-och -stort-misstag; John Söderberg, “Navid Modiri: 'Jag står för det öppna samtalet utan kompromiss," Dagens Media, February 9, 20I9, https://www .dagensmedia.se/medier/radio-podd/navid-modiri-jag-star-for-det-oppna -samtalet-utan-kompromiss; Sam Sundberg, "'Ett klumpigt misstag att lägga ut podden den dagen,'” Svenska Dagbladet, April 7, 2019, https:// www.svd.se/navid-modiri-skulle-se-ett-varde-i-att-bjuda-in-breivik.
} 
gatekeeping even further. It is up to the viewers and listeners to separate the good from the bad, serious discourse from satire. ${ }^{57}$ Accordingly, the debate is about the current power struggle between two different media systems, alternative media without traditional gatekeeping functions, and traditional media dependent on publishing decisions and selectivity.

As far as the economic side of things are concerned, the podcasts are part of a new market, quite different from both the Swedish and the American media markets, and many of the guests could be considered stars in the heaven of alternative media. Hur kan vi? was launched by way of crowdfunding on Kickstarter and is supported via Patreon and Swish, two channels for the handling of donations. Consequently, closely related to the Swedish debate on gatekeeping is another debate, in new and traditional media, on this new system for financial support..$^{8}$ The conversation form

${ }_{57}$ See, e.g., Theodore Kupfer, “Joe Rogan's Boundary-Free Arena," National Review, April I3, 2018, https://www.nationalreview.com/2018 /o4/joe-rogan-podcast-free-speech-zone-non-mainstream-thought; Michael Blight, “'A Conversation isn't a Co-Sign:' An Investigation of Joe Rogan and Deplatforming," Media Commons, July 31, 2019, http://mediacommons.org/imr/content/\%E2\% $80 \%$ C -conversation -isnt-co-sign \% E2 \% 80\% 9D-investigation-joe-rogan-and-deplatforming; Dani Di Placido, “Twitter Doesn't Seem to Understand Joe Rogan's Podcast," Forbes, January 24, 2020, https://www.forbes.com/sites /danidiplacido/2020/oI/24/twitter-doesnt-seem-to-understand-joe -rogans-podcast/\#4b89fdI47 Ibd; Devin Gordon, "Why Is Joe Rogan So Popular?," The Atlantic, August I9, 2019, https:/www.theatlantic.com /entertainment/archive/20I9/o8/my-joe-rogan-experience/594802; http:// www.mediafiledc.com/time-end-joe-rogan-experience. The Joe Rogan Experience has also been criticized for inviting too many men, for spreading fake news, for being shallow, and for not being honest about his political conviction. See, e.g., Therese Larsson Hultin, “Miljoner män följer Rogan: 'Man får en annan bild.' Svenska Dagbladet, January 22, 2020, https://www.svd.se/miljoner-man-foljer-rogan-man-far-en-annan-bild.

$5^{8}$ Sundberg, “'Ett klumpigt misstag att lägga ut podden den dagen”"; Brit Stakston, "Så trivialiserar Navid Modiri en högerextrem propagandist," Dagens Nyheter, January 3 I, 20I9, https://www.dn.se/kultur -noje/kulturdebatt/sa-trivialiserar-navid-modiri-en-hogerextrem-propa gandist; Marcus Joons, “Granskade Lamotte: 'Sedan tog det hus i helvete,"” Svenska Dagbladet, January II, 2020, https:/www.svd.se/har-stalls -svensk-sanning-om-journalistik-pa-huvudet. 
is described as a cheap and effective way to sell controversial opinions directly to the audience, via Kickstarter and Swish, and the soundness of fans directly supporting their favorite alternative media and thus indirectly influencing their content is questioned.

The Joe Rogan Experience is funded through ads and commercial endorsements on YouTube and via iTunes. Both YouTube and Patreon, as private, highly influential companies, have been criticized for endangering free speech through so-called deplatforming and demonetizing of certain channels and outlets with supposed offensive content. ${ }^{59}$ These controversies, and the dangers of the monopoly of Google and YouTube and its effects on free speech, as well as the hate speech policy of Twitter, have been topics of discussion on both podcasts. The Joe Rogan Experience and Hur kan vi? are thus part of a new media economy as well as channels for discussions of this economy and its dangers of fostering new and different monopolies of knowledge and power. You can almost experience, when watching and listening to these podcasts, the theories of Innis and Peters, on the bias of media and media as infrastructures, being negotiated before your eyes and ears.

Joe Rogan's podcast has recently been under attack in a context related to political power. In August 2019, Bernie Sanders guested The Joe Rogan Experience (like other candidates, Andrew Yang and Tulsi Gabbard, before him) for an hour-long discussion on politics and media. ${ }^{60}$ When asked, on a recent episode, who he was planning to vote for in the Democratic primaries, Joe said about Bernie Sanders: "I believe in him, I like him-I like him a lot," nodding to the time he had interviewed Sanders on his show last year. "He's been insanely consistent his entire life." ${ }^{\mathrm{I}}$ The Sanders campaign used this and tweeted out a video of Rogan's endorsement. The reactions were excessive. Sanders was recommended to reconsider the video, and Rogan was accused of attacking transgender people, gay men, women, people

59 "Joe Rogan on the Patreon Controversy," YouTube, December I9, 2018, https://www.youtube.com/watch?v=2wsQPFyZghc.

${ }^{60}$ The Joe Rogan Experience, "Episode \# I330 - Bernie Sanders," YouTube, August 6, 20I9, https://www.youtube.com/watch?v=2O-iLkiG_ng.

6I “Joe Rogan Says He's Voting for Bernie," YouTube, January 23, 2020, https://www.youtube.com/watch?v=ve7 $\mathrm{ccl}_{3} \mathrm{YrHU}$. 
of color, and countless marginalized groups, as well as being accused of promoting Islamophobia and for being a bigot. For the frequent viewer and listener of the podcast, it is obvious that the epithets and accusations hurled at Rogan are untrue; they seem to be the result of a misreading (willful or not) of the Joe Rogan discourse and a misunderstanding of the new media logics characteristic of podcasting. Some journalists defended Rogan; some piled on. ${ }^{62}$ Some commentators highlighted an important argument: Joe Rogan is so influential that any serious presidential candidate should accept his endorsement. The Joe Rogan Experience has become part of the medial infrastructure of political power in the USA. ${ }^{63}$

The Joe Rogan Experience and Hur kan vi? are part of an emerging medial infrastructure, including new controlling agencies, new financial services, and new channels of knowledge and politics. The podcasts are also forums for ongoing conversations about these issues, and the shaping of a new cultural self-understanding.

${ }_{62}$ Matt Stevens, "Why a Joe Rogan Endorsement Could Help (or Backfire on) Bernie Sanders," New York Times, published January 24, 2020, updated January 26, 2020, https://www.nytimes.com/2020/0I/24/us/politics /bernie-sanders-endorsement-joe-rogan.html;BobbyAzarian,"SomeMedia Outlets Are Gaslighting Us about Joe Rogan,” Psychology Today, January 25, 2020, https://www.psychologytoday.com/us/blog/mind-in-the -machine/20200I/some-media-outlets-are-gaslighting-us-about-joe -rogan; Dylan Matthews, "The Joe Rogan Controversy Revealed Something Important about the American Left," Vox, January 27, 2020, https://www.vox.com/future-perfect/2020/I/27/2 I08 I 876/joe-rogan -bernie-sanders-henry-kissinger; Tom Slater, "Bernie Sanders, Joe Rogan and the Folly of Purity Politics," Spiked, January 27, 2020, https://www .spiked-online.com/2020/or/27/bernie-sanders-joe-rogan-and-the-folly -of-purity-politics; Simon Chandler, "Joe Rogan Triggers Internet Outrage Because He Endorsed Bernie Sanders," CCN, January 24, 2020, https:// www.ccn.com/joe-rogan-triggers-internet-outrage-because-he-endorsed -bernie-sanders.

${ }^{63}$ Joe Rogan's reaction to the controversy: "Joe Rogan Responds to Bernie Sanders Endorsement Controversy," YouTube, January 3 I, 2020, https:// www.youtube.com/watch?v=P-KjcOQPVeI. See also "Panel Reacts to SJW Freakout of Rogan Bernie Support," YouTube, January 24, 2020, https://www.youtube.com/watch?v=fZwTEbDEQF 4 . 


\section{Conclusion}

In this chapter, I tried to demonstrate how a combination of media scientific analytical approaches can be applied to a current internet phenomenon, the long-form conversation podcast exemplified by The Joe Rogan Experience and Hur kan vi? From the angles of a formal, intermedial analysis, via a media-historical analysis focused on remediation and orality, to a communication-theoretical analysis emphasizing the power dynamics of the infrastructures of media, what these podcasts are all about is the spoken word as a vehicle for and a symbol of freedom of speech.

\section{References}

Assmann, Jan. Cultural Memory and Early Civilization: Writing, Remembrance, and Political Imagination. Ist English ed. Cambridge: Cambridge University Press, 201 I.

Azarian, Bobby. "Some Media Outlets Are Gaslighting Us about Joe Rogan.” Psychology Today, January 25, 2020. https://www .psychologytoday.com/us/blog/mind-in-the-machine/20200 I /some-media-outlets-are-gaslighting-us-about-joe-rogan.

Benson, Phil. The Discourse of YouTube: Multimodal Text in a Global Context. New York: Routledge, 2017.

Blight, Michael. “'A Conversation isn't a Co-Sign:' An Investigation of Joe Rogan and Deplatforming." Media Commons, July 3I, 2019. http://mediacommons.org/imr/content/\%E2\% 80\% $9 \mathrm{C}$-conver sation-isnt-co-sign $\% \mathrm{E}_{2} \% 80 \%{ }_{9} \mathrm{D}$-investigation-joe-rogan -and-deplatforming.

Bolter, Jay David, and Richard Grusin. Remediation: Understanding New Media. Cambridge: MIT Press, I999.

Burgess, Jean, and Joshua Benjamin Green. YouTube: Online Video and Participatory Culture. Cambridge: Polity, 2009.

Chandler, Simon. "Joe Rogan Triggers Internet Outrage Because He Endorsed Bernie Sanders.” CCN, January 24, 2020. https://www .ccn.com/joe-rogan-triggers-internet-outrage-because-he-en dorsed-bernie-sanders.

Comor, Edward. "Harold Innis and 'The Bias of Communication." Information, Communication \& Society 4, no. 2 (200I): 274-294. 
Di Placido, Dani. “Twitter Doesn't Seem to Understand Joe Rogan's Podcast." Forbes, January 24, 2020. https://www.forbes.com/sites /danidiplacido/2020/or/24/twitter-doesnt-seem-to-understand -joe-rogans-podcast/\#3 553997 I bde.

Durham Peters, John. The Marvelous Clouds: Toward a Philosophy of Elemental Media. Chicago, IL: University of Chicago Press, 2015.

Ekström, Andreas. “Navid Modiris podd är ansvarslös.” Sydsvenskan, January 30, 20I9. https://www.sydsvenskan.se/20I9-OI-30/navid -modiris-podd-ar-ansvarslos.

Elleström, Lars, ed. "The Modalities of Media: A Model for Understanding Intermedial Relations." In Media Borders, Multimodality and Intermediality, I I-48. Basingstoke: Palgrave Macmillan, 20I0.

Elleström, Lars. Media Transformation: The Transfer of Media Characteristics Among Media. Basingstoke: Palgrave Macmillan, $20 \mathrm{I} 4$.

Finnegan, Ruth. Literacy and Orality: Studies in the Technology of Communication. Oxford: Basil Blackwell, I988.

Foka, Anna, and Viktor Arvidsson. "Experiential Analogies: A Sonic Digital Ekphrasis as a Digital Humanities Project.” Digital Humanities Quarterly IO, no. 2 (20I6): paragraphs I-50.

Goody, Jack. Myth, Ritual and the Oral. Cambridge: Cambridge University Press, 2010.

Goody, Jack, and Ian Watt. "The Consequences of Literacy." Comparative Studies in Society and History 5, no. 3 (April I963): 304-345.

Gordon, Devin. "Why Is Joe Rogan So Popular?” The Atlantic, August I9,20I9. https://www.theatlantic.com/entertainment/archive/20I9 /o8/my-joe-rogan-experience/594802.

Guwallius, Kolbjörn. “'Modiris podd om Förintelsen är ett fullständigt haveri.'” Arbetet, January 29, 20I9. https://arbetet.se/20I9/OI/29 /modiris-podd-om-forintelsen-ar-ett-fullstandigt-haveri.

Havelock, Eric Alfred. The Muse Learns to Write: Reflections on Orality and Literacy from Antiquity to the Present. New Haven, CT: Yale University Press, I986.

Howard Stern website. https://www.howardstern.com. 
Hur kan vi? "Därför ska jag tatuera in Joe Rogans ansikte på min rumpa." YouTube, December 9, 20I9. https://www.youtube.com /watch?v=LLY 3 cItp2so.

Hur kan vi? "Episode \#8: Aron Flam - 'Vi är slavar för staten." You Tube, July 8, 20I8. https://www.youtube.com/watch?v=UarNWZ gzcXc.

Hur kan vi? "Episode \#I I: Jens Ganman - 'Vi lever i en värld där media vrider på verkligheten.'” YouTube, July 22, 20I8. https:// www.youtube.com/watch?v=KZB7SO०J3wE.

Hur kan vi? "Episode \#44: Ingrid Carlqvist - 'Hijaben används för att män ska få veta vilka kvinnor som får våldtas." YouTube, January 27, 20I9. https://www.youtube.com/watch?v=yLLj2YM wiRM.

Hur kan vi? "Episode \#69: Janne Josefsson - Jag dör om jag slutar jobba." YouTube, June 30, 20I9. https://www.youtube.com/watch ?v=ZwSBoglx6RU.

Innis, Harold A. The Bias of Communication. Toronto: University of Toronto Press, I95I.

Innis, Harold A. Empire and Communications. Toronto and New York: Dundurn Press, 2007 [I950].

IntellectualDarkWebwebsite.https://intellectualdarkweb.site/vanguards -of-the-intellectual-dark-web.

Internet Archive website. "Opie and Anthony Radio Show Archive." https://archive.org/details/opieandanthonyarchive?tab=about.

"Joe Rogan on Being in the Intellectual Dark Web." YouTube, July 26, 20I 8. https://www.youtube.com/watch?v=spb8bYIfPig.

"Joe Rogan on the Influence of Opie \& Anthony." YouTube, December 6, 20I7. https://www.youtube.com/watch?v=ttZZ30 BwHbI.

"Joe Rogan on the Patreon Controversy." YouTube, December I9, 20I 8. https://www.youtube.com/watch?v=2wsQPFyZghc.

"Joe Rogan Responds to Bernie Sanders Endorsement Controversy." YouTube, January 3I, 2020, https://www.youtube.com/watch?v $=\mathrm{P}-\mathrm{Kj}$ cOQPVeI. 
“Joe Rogan Says He’s Voting for Bernie.” YouTube, January 23, 2020. https://www.youtube.com/watch?v=ve7ccl 3 YrHU.

Johansson, Christer, and Sonya Petersson. "Introduction." In The Power of the In-Between: Intermediality as a Tool for Aesthetic Analysis and Critical Reflection, edited by Sonya Petersson, Christer Johansson, Magdalena Holdar, and Sara Callahan, I-2 I. Stockholm: Stockholm University Press, 20 I 8.

Joons, Marcus. “Granskade Lamotte: 'Sedan tog det hus i helvete." Svenska Dagbladet, January I I, 2020. https://www.svd.se /har-stalls-svensk-sanning-om-journalistik-pa-huvudet.

Kittler, Friedrich A. Gramofon. Film. Typewriter. Berlin: Brinkman and Bose, 1986.

Korn, Dan. "Det fria samtalet har en gräns, Navid Modiri." Expressen, February I4, 20I9. https://www.expressen.se/kultur/ide/det-fria -samtalet-har-en-grans-navid-modiri.

Kupfer, Theodore. "Joe Rogan's Boundary-Free Arena.” National Review, April I3, 201 8. https://www.nationalreview.com/2018/04 /joe-rogan-podcast-free-speech-zone-non-mainstream-thought.

Larsson Hultin, Therese. "Miljoner män följer Rogan: 'Man får en annan bild." Svenska Dagbladet, January 22, 2020. https://www .svd.se/miljoner-man-foljer-rogan-man-far-en-annan-bild.

Llinares, Dario, Neil Fox, and Richard Berry, eds. Podcasting New Aural Cultures and Digital Media. Cham: Springer International Publishing, 20I 8.

Lund, Hans, ed. Intermedialitet: Ord, bild och ton i samspel. Lund: Studentlitteratur, 2002.

Matthews, Dylan. “The Joe Rogan Controversy Revealed Something Important about the American Left." Vox, January 27, 2020. https://www.vox.com/future-perfect/2020/I/27/2 I08 I 876/joe -rogan-bernie-sanders-henry-kissinger.

McLuhan, Marshall. Understanding Media: The Extensions of Man. Critical ed. Corte Madera: Ginko Press, 2003 [1964].

Media Borders, Multimodality and Intermediality, edited by Lars Elleström. Basingstoke: Palgrave Macmillan, 2ого. 
Mitchell, W. J. T., and Mark B. N. Hansen, eds. "Introduction.” In Critical Terms for Media Studies, vi-xxii. Chicago, IL: University of Chicago Press, 20 Io.

Mitchell, W. J. T. “There Are No Visual Media.” Journal of Visual Culture 4 (2005): 257-266.

Munson, Wayne. All Talk: The Talkshow in Media Culture. Philadelphia, PA: Temple University Press, I993.

Ölmedal, Ida. “Navid Modiri och högerextremismen.” Sydsvenskan, February 3, 20I9. https://www.sydsvenskan.se/2019-02-03/navid -modiri-och-hogerextremismen.

Ong, Walter J. Rhetoric, Romance, and Technology: Studies in the Interaction of Expression and Culture. Ithaca, NY: Cornell University Press, I97I.

Ong, Walter J. Orality and Literacy: The Technologizing of the Word. London: Methuen, I982.

"Panel Reacts to SJW Freakout of Rogan Bernie Support." YouTube, January 24, 2020. https://www.youtube.com/watch?v=fZw TEbDEQF 4 .

Peirce, Charles S. "Logics as Semiotic: The Theory of Signs." In Semiotics: An Introductory Anthology, edited by Robert E. Innis, I-23. Bloomington, IN: Indiana University Press, I985.

Rågsjö Thorell, Andreas. "Navid Modiri svarar på kritiken: 'Ett olyckligt och stort misstag." Resumé, January 3I, 20I9. https:// www.resume.se/kommunikation/media/navid-modiri-svarar -pa-kritiken-ett-olyckligt-och-stort-misstag.

Rajewsky, Irina O. "Intermediality, Intertextuality, and Remediation." Intermediality: History and Theory of the Arts, Literature and Technologies, no. 6 (2005): 43-64.

Rajewsky, Irina O. "Border Talks: The Problematic Status of Media Borders in the Current Debate about Intermediality." In Media Borders, Multimodality and Intermediality, edited by Lars Elleström, 5I-68. Basingstoke: Palgrave Macmillan, 2010.

“Real Time with Bill Maher." You Tube. https://www.youtube.com /channel/UCy6kyFxaMqGtpE3pQTflK8A. 
Slater, Tom. "Bernie Sanders, Joe Rogan and the Folly of Purity Politics." Spiked, January 27, 2020. https://www.spiked-online .com/2020/OI/27/bernie-sanders-joe-rogan-and-the-folly-of -purity-politics.

Söderberg, John. "Navid Modiri: 'Jag står för det öppna samtalet utan kompromiss." Dagens Media, February 9, 2019. https:// www.dagensmedia.se/medier/radio-podd/navid-modiri-jag -star-for-det-oppna-samtalet-utan-kompromiss.

Stakston, Brit. "Så trivialiserar Navid Modiri en högerextrem propagandist." Dagens Nyheter, January 3 I, 2019. https://www.dn.se /kultur-noje/kulturdebatt/sa-trivialiserar-navid-modiri-en-hoger extrem-propagandist.

Stevens, Matt. "Why a Joe Rogan Endorsement Could Help (or Backfire on) Bernie Sanders.” New York Times, January 24, 2020, updated January 26, 2020. https://www.nytimes.com/2020/or/24 /us/politics/bernie-sanders-endorsement-joe-rogan.html.

Stone, Alice. "Why Is 'The Joe Rogan Experience' Podcast so Popular?" Showbiz CheatSheet, February 5, 2020. https://www .cheatsheet.com/entertainment/why-is-the-joe-rogan-experience -podcast-so-popular.html.

Sundberg, Sam. "'Ett klumpigt misstag att lägga ut podden den dagen." Svenska Dagbladet, April 7, 2019. https://www.svd.se /navid-modiri-skulle-se-ett-varde-i-att-bjuda-in-breivik.

“The Grievance Studies Affair." YouTube. Last updated April 23, 20I9. https://www.youtube.com/playlist?list=PLLHyNSlsz44-m MSAXVWXjwRc8KOlA8Vrg.

The Joe Rogan Experience. "Episode \#II9I: Peter Boghossian \& James Lindsay." YouTube, October 30, 201 8. https://www.youtube .com/watch?v=AZZNvTivaJg.

The Joe Rogan Experience. "Episode \# 1330 - Bernie Sanders." YouTube, August 6, 20I9. https://www.youtube.com/watch?v=2 O-iLkiG_ng.

The Joe Rogan Experience. "Episode \# I4 I3 - Bill Maher." YouTube, January I7, 2020. https://www.youtube.com/watch?v=-KQGZa773sI.

The Joe Rogan Experience website. https://www.joerogan.com. 
The YouTube Reader, edited by Pelle Snickars and Patrick Vonderau. Stockholm: National Library of Sweden, 2009.

Wolf, Werner. The Musicalization of Fiction: A Study in the Theory and History of Intermediality. Amsterdam: Rodopi, I999.

Wolf, Werner. "The Relevance of Mediality and Intermediality to Academic Studies of English Literature [2008]." In Selected Essays on Intermediality by Werner Wolf (I992-20I4): Theory and Typology, Literature-Music Relations, Transmedial Narratology, Miscellaneous Transmedial Phenomena, edited by Bernhart Walter and Werner Wolf, I27-I 52. Leiden: Brill, 20 I 8.

“Ztv Knesset.”YouTube. https://www.youtube.com/channel/UCFbXd DDRFogVAnPt2cFr-bA/videos.

YouTube Help. "Report inappropriate content.” Accessed February 26, 2020. https://support.google.com/youtube/answer/2802027? $\mathrm{co}=$ GENIE.Platform $\%{ }_{3}$ DAndroid\&hl=en 